\title{
8
}
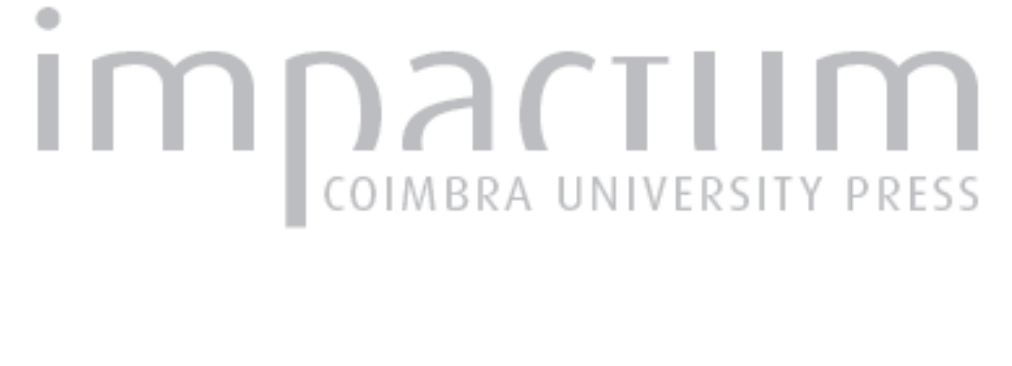

\section{A colonização portuguesa na região de Cabo Frio (Rio de Janeiro, Brasil) e o desenvolvimento da atividade piscatória}

Pereira, Olegário Nelson Azevedo; Castro, Elza Maria Neffa Vieira de;

Accessed : $\quad$ 26-Apr-2023 00:44:26

A navegação consulta e descarregamento dos títulos inseridos nas Bibliotecas Digitais UC Digitalis, UC Pombalina e UC Impactum, pressupõem a aceitação plena e sem reservas dos Termos e Condições de Uso destas Bibliotecas Digitais, disponíveis em https://digitalis.uc.pt/pt-pt/termos.

Conforme exposto nos referidos Termos e Condições de Uso, o descarregamento de títulos de acesso restrito requer uma licença válida de autorização devendo o utilizador aceder ao(s) documento(s) a partir de um endereço de IP da instituição detentora da supramencionada licença.

Ao utilizador é apenas permitido o descarregamento para uso pessoal, pelo que o emprego do(s) título(s) descarregado(s) para outro fim, designadamente comercial, carece de autorização do respetivo autor ou editor da obra.

Na medida em que todas as obras da UC Digitalis se encontram protegidas pelo Código do Direito de Autor e Direitos Conexos e demais legislação aplicável, toda a cópia, parcial ou total, deste documento, nos casos em que é legalmente admitida, deverá conter ou fazer-se acompanhar por este aviso.
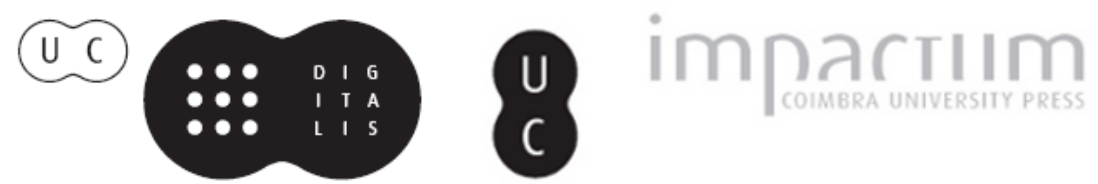


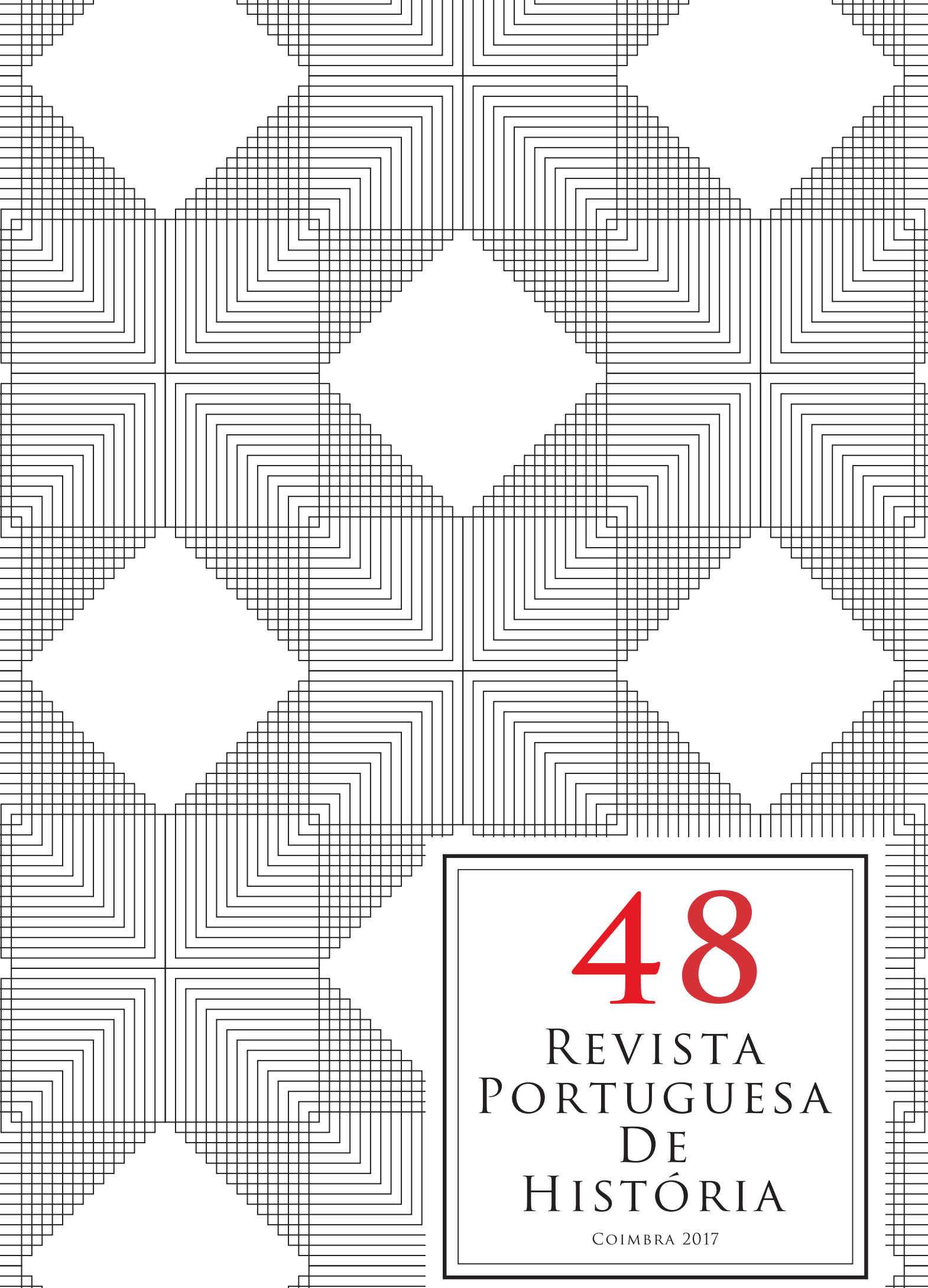




\title{
A colonização portuguesa na região de Cabo Frio (Rio de Janeiro, Brasil) e o desenvolvimento da atividade piscatória
}

\section{Portuguese colonization in the Cabo Frio region (Rio de Janeiro, Brazil) and the development of fishing activity}

\author{
Olegário Nelson Azevedo Pereira ${ }^{1}$ \\ Universidade do Estado do Rio de Janeiro (PPG-MA / UERJ) \\ Centro de Estudos da População Economia e Sociedade/ FAPERJ/CEPESE \\ olegario.pereira@hotmail.com \\ Elza Maria NefFa Vieira de Castro \\ Universidade do Estado do Rio de Janeiro (PPG-MA / UERJ) \\ elzaneffa@gmail.com \\ MARIA Rosário BAstos \\ Universidade Aberta do Porto
} Centro de Investigação Transdisciplinar Cultura, Espaço e Memória/ CITCEM/FLUP Maria.Bastos@uab.pt Jõ̃o Alveirinho DiAs CIMA - Centro de Investigação Marinha e Ambiental da Universidade do Algarve jdias@ualg.pt

Maria Antonieta da Conceição Rodrigues Faculdade de Geologia Universidade do Estado do Rio de Janeiro - UERJ tutucauerj@gmail.com

Luís CANCEla da Fonseca MARE/Laboratório Marítimo da Guia, Portugal Centro de Ciências e Tecnologias da Água Universidade do Algarve lcfonseca@fc.ul.pt

Texto recebido em/Text submitted on: 18/01/2017 Texto aprovado em/Text approved on: 30/03/2017

Resumo:

A região de Cabo Frio, área objeto deste estudo, está localizada na baixada litorânea do Estado do Rio de Janeiro, Brasil. As
Abstract:

The Cabo Frio region, the object area of this study, is located in the coastal lowlands of the State of Rio de Janeiro, Brazil. The

${ }^{1}$ Agradece-se o apoio da Fundação para a Ciência e Tecnologia (FCT) através do projeto UID/MAR/04292/2013 atribuído ao MARE. O primeiro autor agradece à Fundação Carlos Chagas Filho de Amparo à Pesquisa do Estado do Rio de Janeiro (FAPERJ), a bolsa de estudos concedida através do processo E-26/201.582/14. 
suas condições naturais, nomeadamente a existência do sistema lagunar de Araruama e a ocorrência do fenómeno da ressurgência no seu litoral, proporcionaram uma zona favorável à exploração de recursos marinhos, fomentando a fixação humana e o posterior desenvolvimento da pesca lagunar e costeira. Nesse sentido, a atividade apesar de ser praticada pelos povos indígenas estabelecidos na região, no século dezassete, com a efetivação da colonização portuguesa em Cabo Frio observou-se a sua intensificação e desenvolvimento. Tendo em conta as caraterísticas do meio no propiciar de recursos piscícolas, pretende-se analisar diacronicamente a evolução da prática piscatória na região, por meio da investigação de documentação histórica.

\section{Palavras-chave:}

História Ambiental; Sistemas lagunares; Zonas costeiras; Recursos marinhos. natural conditions, such as the existence of the Araruama lagoonal system and the occurrence of the resurgence phenomenon on the seashore, provided a rich area for exploitation of marine resources, promoting human settlement and the subsequent development of lagoonal and coastal fishing. Despite the activity was accomplished by indigenous people established in the region, in the seventeen century, with the arrival of Portuguese settlers to Cabo Frio, its development was observed. Taking into account the characteristics of the environment in the provision of fish resources, we intend to analyse diachronically the evolution of the fishing practice, through the investigation of historical documentation.

Keywords:

Environmental History; Lagoon systems; Coastal areas; Marine resources. 


\section{Introdução}

A região de Cabo Frio, área objeto deste estudo, está localizada na baixada litorânea do Estado do Rio de Janeiro, Brasil (figura 1). As suas condições naturais proporcionaram uma zona favorável à exploração de recursos marinhos, fomentando a fixação humana e o posterior desenvolvimento da pesca lagunar e costeira. Trata-se de uma atividade com uma longa tradição, sendo praticada pelos povos indígenas como meio de subsistência, aplicando técnicas piscatórias mais simples que aquelas posteriormente introduzidas pela colonização portuguesa. Os portugueses chegaram a Cabo Frio no século XVI. A riqueza da região em pau-brasil, produto valioso e cobiçado na Europa, proporcionou o estabelecimento de uma feitoria com o objetivo de controlar a área e de servir como entreposto comercial. Num primeiro momento da colonização, foi impossível a dominação e ocupação territorial por parte dos portugueses. Questões como a falta de efetivos humanos e o constante ambiente de confronto bélico com os indígenas e com os corsários franceses e holandeses que assolavam aquele litoral explorando pau-brasil, traduziram-se em uma colonização temporária da região. Efetivada nos inícios do século XVII, após a expulsão definitiva dos franceses, do controle das investidas dos corsários e da subjugação dos indígenas, fundou-se, oficialmente, a capitania de Cabo Frio ${ }^{2}$. Neste primeiro momento de ocupação portuguesa, a exploração dos recursos naturais voltou-se especialmente para o pau-brasil. No entanto, numa fase subsequente, as condições do meio, nomeadamente devido à existência do sistema lagunar de Araruama e à ocorrência do fenómeno da ressurgência no seu litoral, potenciaram a exploração dos recursos marinhos. Nesse sentido, o pescado foi um recurso essencial para o desenvolvimento da região e, como se verá, é notória a crescente exploração dos recursos pesqueiros. Através da análise de documentação histórica, pretende-se, com este estudo, analisar diacronicamente a evolução da prática piscatória na região de Cabo Frio, levando em consideração as caraterísticas do meio no propiciar desses recursos.

\footnotetext{
${ }^{2}$ Alberto Ribeiro Lamego, O Homem e a Restinga, vol. IV, Rio de Janeiro, IBGE, 1946, p. 75-85. Hilton Massa, Cabo Frio Histórico-Politico, Cabo Frio, Prefeitura Municipal de Cabo Frio, Inelivro, 1980, p. 23-37.
} 
Olegário Nelson Azevedo Pereira/Elza Maria Neffa Vieira de Castro/ Maria Rosário Bastos/João Alveirinho Dias/

Maria Antonieta da Conceição Rodrigues/Luís Cancela da Fonseca

\section{Condições naturais e a potencialidade de exploração dos recursos piscatórios}

A área objeto deste estudo localiza-se na região das baixadas litorâneas do estado do Rio de Janeiro (figura 1). Constituída por uma planície sedimentar de baixa altitude, esta região é caraterizada pela presença de vários sistemas lagunares costeiros, cujo confinamento se deveu à formação de um conjunto de restingas duplas ${ }^{3}$.

\section{Figura 1 - Localização da área de estudo}

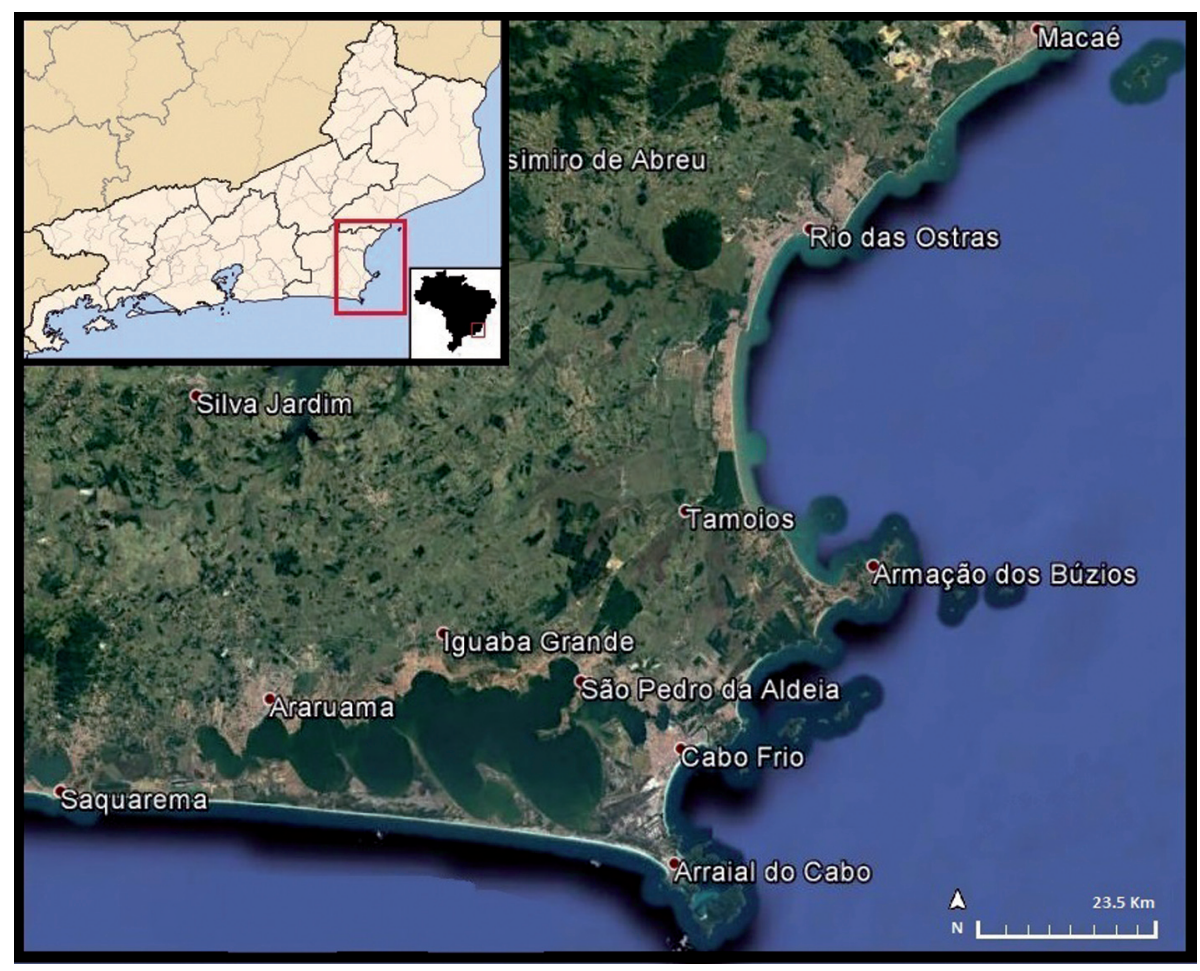

${ }^{3}$ Gilberto T. M. Dias and Björn Kjerfve, "Barrier and Beach Ridge Systems of the Rio de Janeiro Coast" in Sérgio R. Dillenburg and Patrick A. Hesp (ed.) Geology and Geomorphology of Holocene Coastal Barriers of Brazil - Lecture Notes in Earth Sciences, 107, Berlim, Springer-Verlag, 2009, p. 225-252. 
Entre esses sistemas, destaca-se o de Araruama, o qual apresenta uma extensão de cerca de 220 quilómetros quadrados, perímetro de cerca de 160 quilómetros, uma profundidade média de 2,9 metros com um volume de 636 milhões de metros cúbicos, e tempo estimado de renovação de suas águas de 83,5 dias ${ }^{4}$. O corpo hídrico lagunar de Araruama foi confinado pela restinga de Massambaba. Para Alberto Lamego, esta restinga desenvolveu-se através da acumulação de grandes quantidades de areias, transportadas longitudinalmente na direção de oeste para leste, através das correntes de deriva litorânea ${ }^{5}$. Uma vez depositadas, fomentaram a formação de extensos cordões arenosos, confinando enseadas que existiam na região. Posteriormente, verificou-se que a constituição do sistema lagunar de Araruama era resultado de sucessivas subidas e descidas do nível do mar. A gênese das duas séries de cordões litorâneos encontrar-se-ia nesse avanço marítimo, constituindo-se em idades diferentes, a flandriana e a pós-flandriana ${ }^{6}$. Investigações demonstraram que a formação de Araruama como corpo hídrico lagunar, confinado pela restinga de Massambaba, se deveu a uma complexidade de eventos geológicos e de variações do nível do mar. Esta sucessão de eventos ocorridos entre 123 mil até 5 mil anos BP permitiu a formação de dois cordões arenosos em momentos distintos. Nesse sentido, o cordão arenoso mais interior ter-se-á formado durante o período do Pleistoceno, aquando da ocorrência da transgressão marítima e durante a época do Holocénico do período Quaternário, entre 7 mil a 5 mil anos BP, quando a laguna ficou novamente submersa e o cordão arenoso mais próximo ao mar ter-se-á constituído ${ }^{7}$. Considerado um dos maiores sistemas lagunares hipersalinos do mundo, trata-se de uma laguna oligo-mesotrófica. Apesar de apresentar problemas relacionados com a conservação ambiental, estimava-se,

${ }^{4}$ Paulo Bidegain, Plano das Bacias Hidrográficas da Região dos Lagos e do rio São João, Consórcio Intermunicipal para Gestão das Bacias Hidrográficas da Região dos Lagos, Rio São João e Zona Costeira (2005), (http://www.inea.antigo.rj.gov.br/recursos/downloads/ comite_lagos_sao_joao_plano_bacia.pdf, consultado em 21.09.2016).

${ }^{5}$ Alberto Ribeiro Lamego, O Homem e a Restinga ..., cit., p. 10-16.

${ }^{6}$ Ricardo Coe Neto, "Algumas considerações sobre a origem do sistema lagunar de Araruama" in Luiz Drude de Lacerda, Dorothy Sue Dunn de Araujo, Rui Cerqueira e Bruno Turcq (org.) Restingas: origem, estrutura, processos, Niterói, CEUFF, 1984, p. 61-63. Dieter Muehe, "Erosão Costeira - Tendência ou Eventos Extremos? O Litoral entre Rio de Janeiro e Cabo Frio, Brasil", Revista de Gestão Costeira Integrada/Journal of Integrated Coastal Zone Management (2011), (http://www.aprh.pt/rgci/rgci282.html, consultado em 28.09.2016).

${ }^{7}$ Björn Kjerfve, C. A. F. Schettini, Bastiaan Knoppers, Guilherme Lessa and H. O. Ferreira, "Hydrology and Salt Balance in a Large, Hypersaline Coastal Lagoon: Lagoa de Araruama, Brazil”, Estuarine, Coastal and Shelf Science, 42 (1996), p. 704. Gilberto T. M. Dias and Björn Kjerfve, Barrier and Beach Ridge..., cit., p. 244-248. 
no ano de 2005, que tinha uma variada presença e diversidade de organismos, identificando-se 98 espécies de algas, 39 de peixes e mais de 100 espécies de invertebrados bentônicos. Entre os ecossistemas costeiros associados, destacam-se as praias, costões rochosos e os manguezais. A atividade piscatória ainda é exercida neste corpo hídrico lagunar ${ }^{8}$.

Aos recursos piscícolas da laguna, acrescem também os marinhos. No litoral de Cabo Frio ocorre o fenómeno de ressurgência costeira ou afloramento costeiro (coastal upwelling), constituído por uma subida de água fria rica em nutrientes, a qual propicia uma produtividade primária elevada e, consequentemente, abundância em termos de pescado9 ${ }^{9}$. Apesar de a ressurgência ocorrer em sete regiões da costa sudoeste e sul do Brasil, a de maior intensidade ocorre neste litoral, atingindo extensões entre os 150 e os 400 quilómetros ${ }^{10}$. Entre a ictiofauna presente em Cabo Frio, destaca-se, pelo seu valor comercial e captura mais elevada, a espécie sardinha-verdadeira (Sardinella brasiliensis). A esta, associam-se outras, como a savelha (Brevoortia aurea), a sardinha-boca-torta (Cetengraulis edentulus), a sardinha-lage (Opisthonema oglinum), e ainda predadores, como o bonito-barriga-listada (Katsuwonus pelamis), a cavalinha (Scomber japonicus), o xerelete (Caranx crysos) e o bonito-pintado (Euthynnus alletteratus). A sardinha-verdadeira ocorre especialmente em zonas de ressurgência, sendo a de Cabo Frio das mais importantes zonas de captura do estado do Rio de Janeiro ${ }^{11}$. Aliás, o fenómeno contribui para tornar esta área riquíssima em recursos piscícolas, uma vez que estimativas indicam a ocorrência nas suas águas marítimas costeiras de cerca de quatro centenas de

${ }^{8}$ Paulo Bidegain, Plano das Bacias Hidrográficas..., cit., p. 29-32. Paulo Bidegain e Carlos Bizerril, Lagoa de Araruama - perfil ambiental do maior ecossistema lagunar hipersalino do mundo. Projeto Planágua Semads (2002), (http://www.bibliotecaflorestal.ufv. br/handle/123456789/10812, consultado em 21.09.2016), p. 66-77.

${ }^{9}$ Eliane Gonzales-Rodriguez, Jean Louis Valentin, Dalmo Lacerda André and Salvador Abdala Jacob, "Upwelling and downwelling at Cabo Frio (Brazil): comparison of biomass and primary production responses", Journal of Plankton Research, 14-2 (1992), p. 289-306. Ruben M. Lopes, Mario Katsuragawa, June F. Dias, Monica A. Montú, José H. Muelbert, Charles Gorri and Frederico P. Brandini, "Zooplankton and ichthyoplankton distribution on the southern Brazilian shelf: an overview". Scientia Marina, 70-2 (2006), p. 189-202.

${ }^{10}$ Sérgio Augusto Coelho-Souza, Maria Soledad López, Jean Remy Davee Guimarães, Ricardo Coutinho and Rogério Nader Candella, "Biophysical interactions in the Cabo Frio upwelling system, southeastern Brazil”. Brazilian Journal of Oceanography, 60-3 (2012), p. 354.

${ }^{11}$ Melquíades Pinto Paiva e Paulo César Silva da Motta, "Cardumes da sardinha-verdadeira, Sardinella brasiliensis (Steindachner), em águas costeiras do estado do Rio de Janeiro, Brasil". Revista Brasileira de Zoologia, 17-2 (2000), p. 339-346. 
espécies piscícolas na superfície e meia-água, assim como nos fundos rasos e profundos ${ }^{12}$.

Estas condições ambientais revelaram-se fundamentais no que diz respeito à potencialidade para a prática piscatória. Por um lado, um litoral sujeito ao fenómeno aludido e do qual resulta o desenvolvimento de teias tróficas exuberantes, as quais suportam uma numerosa variedade de espécies piscícolas marinhas; por outro, a existência de sistemas lagunares confinados ou semi-confinados é particularmente importante para o desenvolvimento da atividade pois, para além de oferecer proteção ao impacto direto do oceano ${ }^{13}$, tais ambientes permitem uma atividade piscatória abundante e variada, uma vez que as lagunas são normalmente criadouros de espécies piscícolas marinhas ${ }^{14}$.

\section{A atividade piscatória indígena}

A região da baixada litorânea do estado do Rio de Janeiro, onde predominam extensos areais, devido às valências ofertadas pelo meio, tornou-se local de excelência para a fixação humana ${ }^{15}$. Embora haja quem defenda uma ocupação anterior ${ }^{16}$, o povoamento do cordão externo holocénico da restinga de Massambaba, que confina a laguna de Araruama, terá ocorrido entre 4500 e 1800 anos antes do presente, quando grupos Sambaquianos, cujo enfoque de exploração se orientava predominantemente para os recursos existentes na área litorânea, em especial os marinhos, se teriam instalado na região ${ }^{17}$. A prática piscatória remonta, portanto, às populações autóctones. Diversos estudos arqueológicos comprovam a exploração dos recursos marinhos pelos povos indígenas ao longo dessa faixa litorânea, tanto na restinga arenosa, quanto

${ }^{12}$ Paulo Bidegain, Plano das Bacias Hidrográficas..., cit., p. 29-32.

${ }^{13}$ Alberto Ribeiro Lamego, O Homem e a Restinga ..., cit., p. 159.

${ }^{14}$ Lísia Maria Cavalcante Bernardes e Nilo Bernardes, "A pesca no litoral do Rio de Janeiro", Revista Brasileira de Geografia, ano XII, n. ${ }^{\circ} 1$ (1950), p. 17. L. V. Barroso, F. C. C. Fabiano, "Estudo da pesca com artes fixas na laguna de Araruama (RJ), Oecologia Brasiliensis, vol. 1 (1995), (www.oads.org.br/livros/26.pdf, consultado em 14.09.2016), p. 569-585.

${ }^{15}$ Alberto Ribeiro Lamego, O Homem e a Restinga ..., cit., p. 69-72.

${ }^{16}$ Lina Maria Kneip, Luciana Pallestrini, "Restingas do Estado do Rio de Janeiro (Nitéroi a Cabo Frio): 8 mil anos de ocupação humana" in Luiz Drude de Lacerda, Dorothy Sue Dunn de Araujo, Rui Cerqueira e Bruno Turcq (org.), Restingas: origem, estrutura, processos, Niterói, CEUFF, 1984, p. 139-146.

${ }^{17}$ Márcia Barbosa da Costa Guimarães, A ocupação pré-colonial da região dos Lagos, RJ: sistema de assentamento e relações intersocietais entre grupos sambaquianos e grupos ceremistas Tupinambá e da tradição Una, vol. I, Universidade de São Paulo (2007), (http://www.teses.usp. br/teses/disponiveis/71/71131/tde-05092007-111015/pt-br.php, consultado em 25.09.2016). 
no entorno lagunar ${ }^{18}$. No momento da chegada dos portugueses, no início do século XVI, a região encontrava-se povoada por duas "nações" indígenas que se contendiam entre si: a Tamoio ${ }^{19}$, ocupando as áreas de lagunas e enseadas, e a Goitacá, ocupando as planícies de restingas ${ }^{20}$. Os Tamoios (ou Tupinambá) pescavam utilizando linhas feitas com uma planta chamada tucum $^{21}$ à qual prendiam espinhas. Os anzóis foram introduzidos posteriormente pelos europeus tal como as redes de maior dimensão, que causavam a admiração dos indígenas devido à quantidade de pescado que permitiam capturar ${ }^{22}$. Não obstante, o tucum também era utilizado no preparo de redes de dimensão reduzida chamadas puçás, com as quais pescavam sobretudo durante a praia-mar, entre outras espécies, principalmente as tainhas ${ }^{23}$. Além da utilização das redes, também aplicavam uma espécie de covos chamados giquís. Quando se tratava da captura de pescado de maiores dimensões, os Tupinambá utilizavam arco e flecha ${ }^{24}$. Já nos cursos

\footnotetext{
${ }^{18}$ Sheila Maria Ferraz Mendonça de Souza, Alfredo A. C. Mendonça de Souza, "Pescadores e Recoletores do litoral do Rio de Janeiro", Arquivos do Museu de História Natural, vol. VI-VII (1981-1982), p. 109-131. Lina Maria Kneip, Luciana Pallestrini, Restingas do Estado do Rio de Janeiro..., cit. p. 139-146. Márcia Barbosa da Costa Guimarães, A ocupação pré-colonial da região dos Lagos... cit., p. 22-23, 42, 94-101.

${ }^{19}$ Trata-se de um termo local atribuído aos índios Tupinambá, os quais ocupavam a região costeira entre o atual estado de São Paulo e a cidade de Cabo Frio no estado do Rio de Janeiro: cf. Carlos Fausto, "Fragmentos de História e Cultura Tupinambá: da Etnologia como instrumento crítico de conhecimento etno-histórico", in Manuela Carneiro da Cunha (org.) História dos Índios no Brasil, São Paulo, Companhia das Letras, Secretaria municipal de cultura, Fapesp, 1992, p. 383.

${ }^{20}$ Alberto Ribeiro Lamego, O Homem e a Restinga ..., cit., p.72, 75.

${ }^{21}$ Segundo Gabriel Soares de Souza, o Tucum é uma erva da qual os indígenas retiravam das suas folhas uma espécie de linho comparável a seda, entrelaçando-o, de forma a produzir o fio de pesca. As linhas eram tão resistentes que nenhuma espécie de peixe as quebrava: Gabriel Soares de Souza, Tratado Discriptivo do Brazil em 1587, Rio de Janeiro, Typographia Universal de Laemmert, 1851, p. 222-223.

${ }^{22}$ Jean de Léry, Viagem à terra do Brasil, São Paulo, Livraria Martins Editora, 1941, p. 148-149. Frei Vicente do Salvador também afirma que os anzóis foram uma introdução dos portugueses, referindo que anteriormente os indígenas usavam um tipo de espinho para pescar: Frei Vicente do Salvador, História do Brasil 1500-1627, Rio de Janeiro, Weiszflog Irmãos, 1918, p. 55.

${ }^{23}$ Talvez por isso Jean de Levy descreva que se os europeus lhes facultassem redes, facilmente as manejavam (Jean de Léry, Viagem à terra do Brasil..., cit., p. 149), pois embora de tamanho mais reduzido já recorriam a esse instrumento piscatório. Hans Staden também refere que as redes indígenas eram de pequena dimensão e feitas com tucum: Hans Staden, Duas Viagens ao Brasil: arrojadas aventuras no século XVI entre os Antropófagos do Novo Mundo, São Paulo, Sociedade Hans Staden, 1942, p. 159.

${ }^{24}$ A utilização de flecha, segundo Gabriel Soares de Souza, resultava do facto de não possuírem anzóis. O autor considera estes indígenas grandes mergulhadores e pescadores: Gabriel Soares
} 
fluviais (e provavelmente nas lagunas ${ }^{25}$ ), a prática era o envenenamento dos peixes recorrendo à planta timbó ou tinguí, rendendo a maior quantidade de pescado capturado ${ }^{26}$. Ao norte de Cabo Frio encontravam-se os Goitacás ${ }^{27}$ habitando a planície deltaica do Rio Paraíba do Sul, uma região de cordões arenosos intercalados por brejos e lagoas ${ }^{28}$. Estes indígenas tiravam proveito das condições do terreno ${ }^{29}$, demonstrando uma perfeita adaptação ao meio em que viviam. Segundo algumas descrições, ao contrário dos Tamoios, não edificavam aldeias. Além disso, não cultivavam a terra, subsistindo através da caça e da pesca ${ }^{30}$. O seu maior património eram os seus arcos, os quais utilizavam para sua defesa e para a caça e pesca. Quanto à última atividade, exerciam-na tanto nos rios, quanto nas lagoas e no mar, sendo descritos como pescadores exímios ${ }^{31}$. Embora a informação quanto aos seus instrumentos e técnicas de pescar não abunde, como a referente aos Tamoios, conclui-se que os mais utilizados pelos indígenas que habitavam a região de Cabo frio seriam

de Souza, Tratado Discriptivo do Brazil em 1587..., cit., p. 93. Do mesmo modo, Hans Staden descreve que os indígenas procuravam apanhar o peixe no mar, flechando-o e depois mergulhando para o capturar: Hans Staden, Duas Viagens ao Brasil..., cit., p. 159.

${ }^{25}$ Além da utilização destas ervas nos cursos fluviais, também a aplicavam em "esteiros de água salgada": Gabriel Soares de Souza, Tratado Discriptivo do Brazil em 1587..., cit., p. 320 .

${ }^{26}$ Francisco Adolpho de Varnhagen, História Geral do Brazil, tomo I, Madrid, Imprensa de V. de Dominguez, 1854, p. 117. Gabriel Soares de Souza, Tratado Discriptivo do Brazil em $1587 \ldots$, cit., p. 320. Esta prática seria semelhante aquela realizada em Portugal e chamada de entroviscada ou troviscada: Sandra Rute Fonseca Gomes, Territórios Medievais do Pescado do Reino de Portugal, Faculdade de Letras da Universidade de Coimbra, (2011), (https://estudogeral. sib.uc.pt/handle/10316/18460, consultado em 19.09.2016), p. 21.

${ }^{27} \mathrm{Em} 1587$, embora fosse a região habitada por este povo, supostamente ter-se-ia afastado do litoral (Gabriel Soares de Souza, Tratado Discriptivo do Brazil em 1587..., cit., p. 80). Segundo o capitão-mor do Rio de Janeiro refere em 1624, os Goitacás ainda habitavam a região (Arquivo Histórico Ultramarino (Lisboa) (a seguir citado com a sigla AHU), Conselho Ultramarino, Brasil, Rio de Janeiro, caixa 1, documento 26, fl.1v.). Alberto Ribeiro Lamego refere a mesma ocupação territorial, embora cogite a possibilidade de estes indígenas estarem distribuídos por um território que se estendia até próximo da Baía de Guanabara, no Rio de Janeiro, Alberto Ribeiro Lamego, O Homem e o brejo, Rio de Janeiro: IBGE, 1945, p. 34.

${ }^{28}$ Alberto Ribeiro Lamego, O Homem e o brejo..., cit., p. 3-23.

${ }^{29}$ Por exemplo, Frei Vicente do Salvador explicava a sua difícil subjugação “ [...] porque vivem em terras alagadiças mais a modo de homens marinhos que terrestres e, quando se ha de chegar ás mãos com elles, mettem-se dentro das águas, aonde se não pode entrar nem a pé, nem a cavallo.": Frei Vicente do Salvador, História do Brasil 1500-1627..., cit., p. 622. Como se verá somente em princípio do século XVII se conseguem as pazes com este povo, embora não fossem totalmente respeitadas.

${ }^{30}$ Gabriel Soares de Souza, Tratado Discriptivo do Brazil em 1587..., cit., p. 99-100.

${ }^{31}$ Alberto Ribeiro Lamego, O Homem e o brejo, Rio de Janeiro: IBGE, 1945, p. 37. 
o emprego do arco e flecha, a pesca à linha, as redes de pequena dimensão, a utilização de instrumentos semelhantes a covos e o envenenamento recorrendo à planta timbó ou tinguí.

\section{A colonização portuguesa em Cabo Frio e o desenvolvimento da atividade piscatória}

\subsection{Os primórdios da ocupação portuguesa}

As primeiras incursões portuguesas no território litorâneo do sudeste do Brasil revestem-se de um caráter exploratório e geopolítico, sendo mais tardia a fixação populacional. A instalação de entrepostos servia como pontos de apoio e de exploração. No litoral do estado do Rio de Janeiro, o entreposto de Cabo Frio implementado entre 1503 e 1504 é um exemplo desses primeiros empreendimentos. Durante a maior parte do século XVI, a presença dos europeus no litoral fluminense é marcada por constantes batalhas entre os portugueses e os franceses envolvendo os povos indígenas ${ }^{32}$. Tais circunstâncias não permitiram o pleno assentamento populacional português em Cabo Frio ${ }^{33}$. Distante da cidade do Rio de Janeiro mais intensamente ocupada pelos portugueses, a região era frequentada pelos franceses e corsários de outras nacionalidades que aí se deslocavam para explorar o pau-brasil ${ }^{34}$. As circunstâncias naturais tornavam este litoral num ponto de paragem para o contrabando dessa madeira, para suprimento de mantimentos e aguada (abastecimento de água doce) ${ }^{35}$.

32 José de Souza Azevedo Pizarro de Araújo, Memorias Historicas do Rio de Janeiro e das Provincias Annexas A'Jurisdicção do Vice-Rei do Estado do Brasil, Dedicadas a El-Rei Nosso Senhor D. João VI, tomo I, Rio de Janeiro, Impressão Régia, 1820. Alberto Ribeiro Lamego, O Homem e a Restinga..., cit., p. 75-85. Hilton Massa, Cabo Frio Histórico-Político..., cit., p. 23-37.

${ }^{33}$ Embora antes de 1658 já houvesse sido instalada uma povoação que, “[...] pelo clima, ou por outros acidentes, se não conservou.": Carta para sua magestade acerca dos Guaitacazes, Documentos Históricos - Correspondência dos governadores geraes: Conde de Castello Melhor, Conde de Athouguia, Francisco Barreto (1648-1672), vol. IV, Bibliotheca Nacional, Rio de Janeiro, 1928, p. 346.

${ }^{34}$ José de Souza Azevedo Pizarro de Araújo, Memorias Historicas do Rio de Janeiro..., cit., tomo II, p. 131-133.

${ }^{35}$ Diversa documentação demonstra as constantes incursões de franceses, bem como de ingleses e holandeses, especialmente durante o século XVII, mesmo após a fundação da cidade de Cabo Frio: e.g. AHU, Conselho Ultramarino, Brasil, São Paulo, Caixa 1, documento 2; AHU, Conselho Ultramarino, Rio de Janeiro, caixa 1, documento 13, fl. 1v.; AHU, Conselho Ultramarino, Brasil, Rio de Janeiro, caixa 1, documento 14; AHU, Conselho Ultramarino, 
A laguna de Araruama, pela sua caraterística de litoral abrigado e por ter fundos suficientes, permitia a navegação das embarcações de calado superior que podiam aportar ao abrigo das condições marítimas ${ }^{36}$. Somente em 1615 é fundada oficialmente a povoação de Cabo Frio e tem inicio o seu povoamento efetivo $^{37}$. Em 1617, ordens régias emanadas de Portugal procuraram fixar duas aldeias de indígenas em Cabo Frio, designando para o efeito Martim de Sá, capitão-mor do Rio de Janeiro, que pretendia constituí-las com índios oriundos de aldeias da Companhia de Jesus situadas em Espírito Santo, São Paulo e Rio de Janeiro ${ }^{38}$. Nesse mesmo ano, no final de Maio, o padre António de Matos, Reitor do Colégio Jesuíta do Rio de Janeiro, adquire terras através de uma sesmaria, para fundar uma aldeia indígena ${ }^{39}$. Em 1619 um padre da Companhia e o capitão-mor de Cabo Frio Estevão Gomes partem em missão para tratar das pazes com os goitacás ${ }^{40}$, enquanto Martim de Sá buscava indígenas do Espírito Santo ${ }^{41}$. A missão teve resultado embora, em 1624, Martim de Sá refira que os Goitacás mesmo aceitando as pazes se insurgiam contra os portugueses ${ }^{42}$. De qualquer modo, houve deslocação de goitacás para a missão jesuíta e áreas a norte, nomeadamente na da Ponta de Búzios (figura 1) e campos de Una (na margem do rio Una, localizado entre Tamoios e a Ponta de Búzios - figura 1), embora não tenha sucedido de forma pacífica ${ }^{43}$. Por essa altura, os jesuítas

Brasil, Rio de Janeiro, caixa 1, documento 15; AHU, Conselho Ultramarino, Brasil, São Paulo, Caixa 5, documento 487.

${ }^{36}$ Tal condição já é referida em 1587 (Gabriel Soares de Souza, Tratado Descriptivo do Brazil em 1587..., cit., p. 80-81.), mantendo-se em 1663 (Padre Simão de Vasconcellos, Chronica da Companhia de Jesu do Estado do Brasil e do que obraram seus filhos nesta parte do Novo Mundo. Em que se trata da entrada da Companhia de Jesu nas partes do Brasil, dos fundamentos que nellas lançaram e continuaram seus religiosos, e algumas noticias antecedentes, curiosas e necessárias das cousas d'aquelle Estado, vol. I, Lisboa, A. J. Fernandes Lopes, 1865, p. LII.).

${ }^{37}$ José de Souza Azevedo Pizarro de Araújo, Memorias Historicas do Rio de Janeiro..., cit., tomo II, p. 131-133. Alberto Ribeiro Lamego, O Homem e a Restinga ..., cit., p. 84-85.

${ }^{38}$ Como se viu, estas áreas geográficas eram ocupadas maioritariamente pelos Tamoios ou Tupinambá entre São Paulo e o Cabo Frio (Carlos Fausto, "Fragmentos de História e Cultura Tupinambá..., cit., p. 383) e daqui até o sul do Espírito Santo pelos Goitacás (Alberto Ribeiro Lamego, O Homem e o brejo..., cit., p. 34).

${ }^{39}$ AHU, Conselho Ultramarino, Brasil, Rio de Janeiro, caixa 18, documento 2038, fol. $17 \mathrm{v}$-18v. A sesmaria foi concedida pelo primeiro capitão-mor de Cabo Frio, Estevão Gomes, tratando-se da localidade de São Pedro da Aldeia (figura 1): Alberto Ribeiro Lamego, O Homem e a Restinga..., cit., p. 94.

${ }^{40}$ AHU, Conselho Ultramarino, Brasil, Rio de Janeiro, caixa 1, documento 15, fl. 2.

${ }^{41}$ AHU, Conselho Ultramarino, Brasil, Rio de Janeiro, caixa 1, documento 20.

${ }^{42}$ AHU, Conselho Ultramarino, Brasil, Rio de Janeiro, caixa 1, documento 26, fl. $1 \mathrm{v}$.

${ }^{43}$ Em 1721, o Prior da Companhia de Jesus, padre António Cardozo, refere "[...] para tal Aldea que ha foi necessario no seu prinçipio puxar com grande uiolencia os Indios que estauaõ pellos 
também estabeleceram uma fazenda de gados e terrenos de cultivo em Macaé (figura 1) ${ }^{44}$. A missão de São Pedro da Aldeia foi suficientemente povoada, pois considerava-se que acrescendo somente dez soldados aos indígenas seria suficiente para a proteção daquele litoral ${ }^{45}$. Com efeito, a localidade fundada pelos jesuítas, tinha em 1684 cerca de 200 habitantes, ao passo que em Cabo Frio (figura 1) eram poucos os moradores, embora não se expresse o seu quantitativo $^{46}$. Outras localidades pontuavam na região. Ao termo de Cabo Frio pertencia a localidade de Saquarema ${ }^{47}$, fundada em 1660 aquando da construção da capela de Nossa Senhora da Nazaré48. Em 1726 também estaria estabelecida a localidade de Araruama (figura 1). Apesar de Alberto Ribeiro Lamego considerar ser de fundação mais recente ${ }^{49}$, o mais certo é ser anterior a essa data pois já se encontrava uma guarnição militar controlando a ancoragem de embarcações inimigas ${ }^{50}$. Conclui-se deste modo que a região em análise começou a ser paulatinamente povoada a partir do século XVII, destacando-se os núcleos populacionais de Cabo Frio, de São Pedro da Aldeia cuja ocupação se estendeu para a Ponta de Búzios e proximidades do rio Una, de Macaé, de Saquarema e de Araruama.

Campos dos Guaitacazes e para isto he que se concederaõ em Mayo de 1617 os campos de Una e ponta dos Buzios em que os tais Indios tem muito largo destricto para suas rossas e fazendas." (AHU, Conselho Ultramarino, Brasil, Rio de Janeiro, caixa 13, documento 1407, fl. 5v.).

${ }^{44}$ Alegavam os religiosos que os terrenos eram pouco produtivos por serem alagadiços, chamavam-se de Campos Novos. Alguns moradores de Cabo Frio exploravam as terras, embora sem consentimento dos religiosos. Junto dos terrenos havia também outras terras da Companhia, onde descansavam os gados (boiadas) que vinham de Campos de Goitacazes para o Rio de Janeiro, sendo habitadas somente por quatro escravos: AHU, Conselho Ultramarino, Brasil, Rio de Janeiro, caixa 13, documento 1407, fl. 5v., 9, 9v.

${ }^{45}$ AHU, Conselho Ultramarino, Brasil, Rio de Janeiro, caixa 1, documento 26, fl. 1v.-2.

${ }^{46}$ AHU, Conselho Ultramarino, Brasil, Rio de Janeiro, caixa 5, documento 503, fl. 1. Em 1727, o capitão-mor do Rio de Janeiro refere que a aldeia da Companhia "[...] he a mais poupuloza e numeroza que tem esta Cappitania [...]" afirmando que inclusive sessenta homens teriam sido enviados à cidade do Rio para trabalhar 3 meses na fortificação da ilha das cobras (AHU, Conselho Ultramarino, Brasil, Rio de Janeiro, caixa 18, documento 2038, fl. 4).

${ }^{47}$ Em 1727, a câmara de Cabo Frio pede que se tribute a água-ardente na cidade e em Saquarema que pertencia ao seu termo (AHU, Conselho Ultramarino, Brasil, Rio de Janeiro, caixa 10, documento 1046).

${ }^{48}$ Alberto Ribeiro Lamego, O Homem e a Restinga ..., cit., p. 98. Um documento de 1727 refere o lugar de Nossa Senhora da Nazaré, integrando Saquarema, confirmando pertencer ao termo de Cabo Frio (AHU, Conselho Ultramarino, Brasil, Rio de Janeiro, caixa 18, documento 2038).

\footnotetext{
${ }^{49}$ Alberto Ribeiro Lamego, O Homem e a Restinga..., cit., p. 86 et seq.

${ }^{50}$ AHU, Conselho Ultramarino, Brasil, Rio de Janeiro, caixa 16, documento 1827.
} 


\subsection{Locais de pescaria}

Com esta ocupação territorial pelos portugueses desenvolvem-se núcleos de povoamento cuja população se voltava para o empreendimento piscatório. Alberto Lamego assevera essa situação quando refere que "Logo após a tomada de Cabo Frio agrupamentos de pescadores nascem nessa costa pródiga de abrigos seguros em suas numerosas enseadas desde a baía Formosa até a Praia Grande na restinga de Massambaba." ${ }^{51}$. Com efeito, no século XVII, as pescarias já estariam estabelecidas. Na Ponta de Búzios, os indígenas desempenhavam essa labuta desde a fundação de São Pedro da Aldeia em $1617^{52}$. O cartógrafo João Teixeira Albernaz, ao descrever o litoral brasileiro, em 1640, ressalta uma enseada junto ao Cabo Frio (figura 2) onde havia muitas pescarias ${ }^{53}$.

\section{Figura 2 - Região litorânea da Capitania de Cabo Frio em 1640, onde se representa a existência de pescarias}

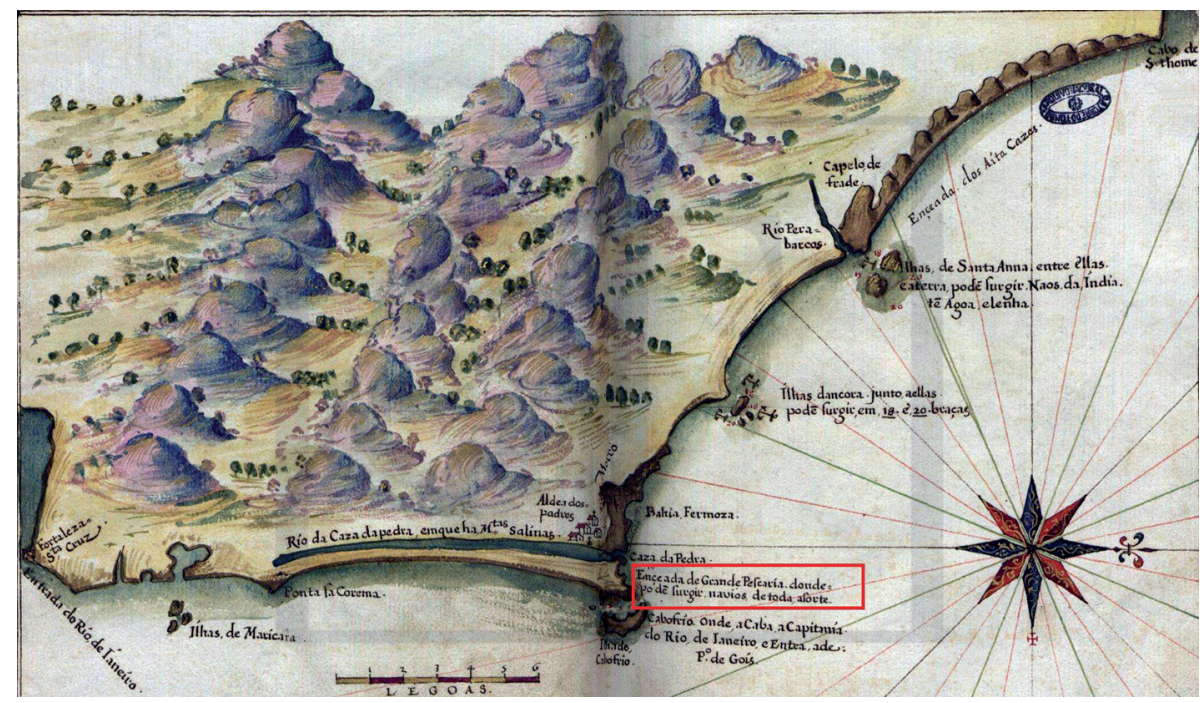

${ }^{51}$ Alberto Ribeiro Lamego, O Homem e a Restinga ..., cit., p. 159.

${ }^{52}$ Num processo entre a Câmara e a Companhia de Jesus o juiz ordinário refere "[...] que os Indios desta Aldeya do Senhor Saõ Pedro, no dystrito do Cabo Frio, leuantaraõ hũa Pescaria hem hũa Paragem chamada a ponta dos Buzios, depois que esta Aldeya se fundou; e nella pescaraõ sempre." AHU, Conselho Ultramarino, Brasil, Rio de Janeiro, caixa 18, documento 2038, fl. 12.

${ }^{53}$ Instituto Arquivos Nacionais/Torre do Tombo (Lisboa), coleção cartográfica, n. ${ }^{\circ}$ 162, microfilmes 58 e 61 (http://digitarq.arquivos.pt/details?id=4162623, consultado em 15.09.2016). 
Na segunda década do século XVIII, além dos indígenas também os moradores de Cabo Frio pescavam na Ponta de Búzios. Daqui tomando direção à cidade de Cabo Frio até a praia de Peró estabeleceram oito "grandes pescarias" ${ }^{54}$. Em 1729, duas descrições apontam algumas das pescarias instaladas entre a restinga de Massambaba e a Ponta dos Búzios, as quais, como se verá, estariam direcionadas para a captura de pelágicos dadas as condições naturais de ressurgência costeira e as artes piscatórias empregues. As descrições são efetuadas por um morador de Cabo Frio e por um morador de Araruama ${ }^{55}$, portanto, conhecedores da sua distribuição por aquele litoral. Segundo a mesma, partindo da restinga de Massambaba, a primeira pescaria era na Praia Grande, seguindo-se na Praia do Anjo. Em frente a esta, localiza-se a ilha do Cabo, a qual era posse da coroa, mas arrendada para a labuta da pesca. Entre a Praia do Anjo e a barra de Cabo Frio (canal de Itajurú) havia pescarias na Praia do Forno, na Prainha, Praia do Canto e Praia do Pontal. Do outro lado da barra, seguiam-se pescarias ao longo da Baía Formosa, na Praia Brava ou Vermelha e na Praia do Peró. Ao final desta baía, na Enseada de Búzios, havia pescarias na Praia da Emerência, de Jerubá ${ }^{56}$, da Ferradurinha, da Ferradura Grande, em outra praia chamada de Praia Brava, na praia de João Fernandes, na da Sardinha e na Praia do Maribondo. A estas seguiam-se as praias onde os índios tinham as pescarias. Todas as pescarias eram de particulares ${ }^{57}$ (figura 3 ).

${ }^{54}$ AHU, Conselho Ultramarino, Brasil, Rio de Janeiro, caixa 18, documento 2038, fls. 1, 6,12 ,

${ }^{55}$ AHU, Conselho Ultramarino, Brasil, Rio de Janeiro, caixa 22, documento 2432, fls. 12 -14 .

${ }^{56}$ Embora o morador de Araruama indique que aqui, por ser o mar revolto, não havia pescarias (AHU, Conselho Ultramarino, Brasil, Rio de Janeiro, caixa 22, documento 2432, fl. 13v.)

${ }^{57} \mathrm{AHU}$, Conselho Ultramarino, Brasil, Rio de Janeiro, caixa 22, documento 2432, fls. 12-14. Os indígenas teriam as suas pescarias na enseada dos Búzios (fl. 16v.-17v.), portanto, as praias da sardinha e do Maribondo; pela descrição, subentende-se localizarem-se nas duas enseadas entre a Praia de João Fernandes e a Praia dos índios. 
Figura 3 - Localização de pescarias no litoral entre a restinga de Massambaba e a Ponta de Búzios em 1729

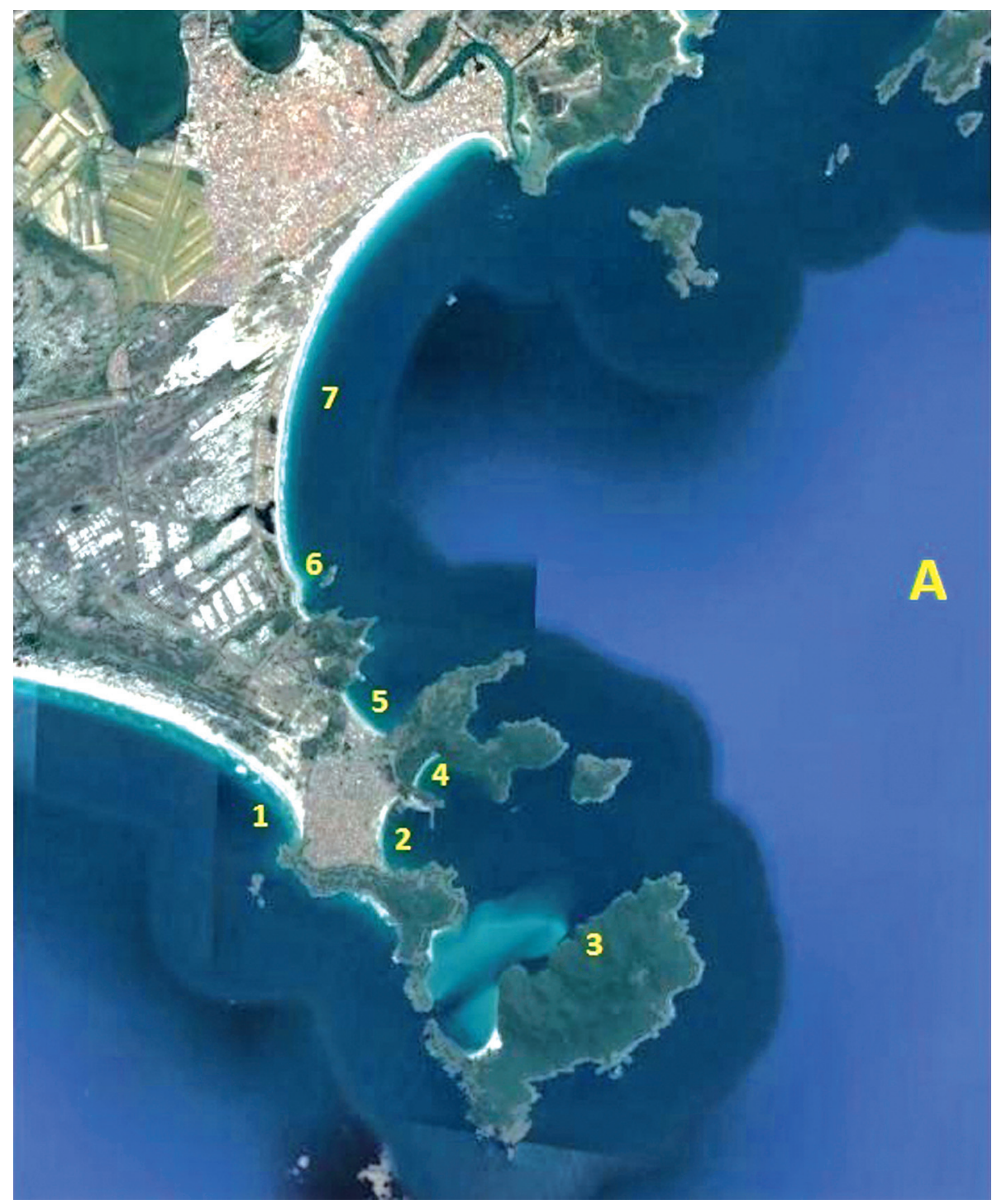

A: Trecho litorâneo entre a Restinga de Massambaba e barra de Cabo Frio (Itajurú) 1 - Praia Grande; 2 - Praia do Anjo; 3 - Ilha do Cabo; 4 - Praia do Forno; 5 - Prainha; 6 - Praia da Canto; 7 - Praia do Pontal 


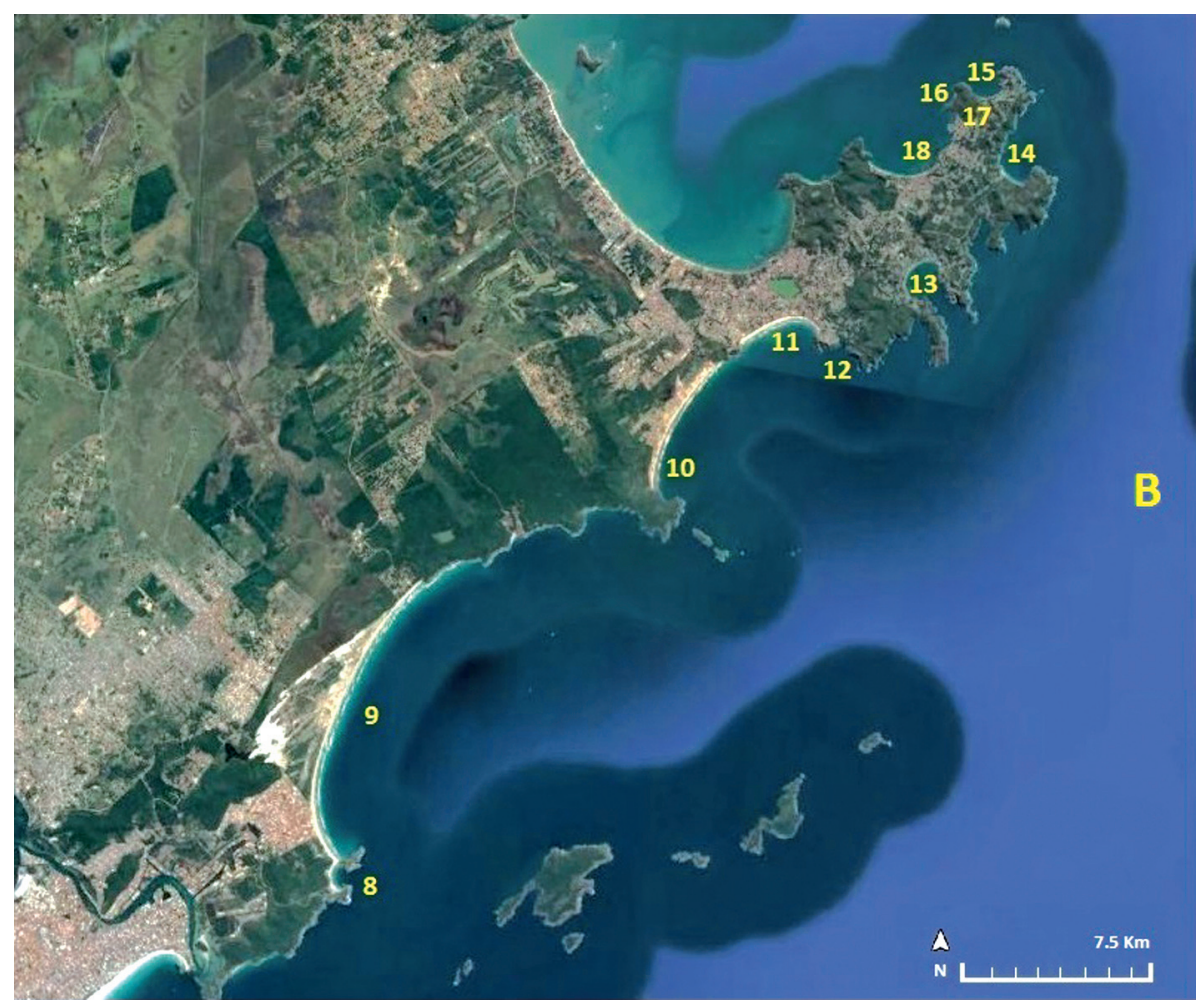

B: Trecho litorâneo entre a barra de Cabo Frio (Itajurú) e a Ponta de Búzios 8 - Praia Brava ou Vermelha; 9 - Praia do Peró; 10 - Praia da Emerência; 11 - Praia de Jerubá; 12 - Praia da Ferradurinha; 13 - Praia da Ferradura Grande; 14 - Praia Brava; 15 - Praia de João Fernandes; 16 - Praia da Sardinha; 17 - Praia do Maribondo; 18 - Praia da pescaria dos Índios.

Em Saquarema também se exercia a atividade piscatória. Embora as descrições aludidas não mencionem as pescarias a sul da Praia Grande na restinga de Massambaba, em 1729 vários moradores da localidade tinham como ofício serem pescadores ${ }^{58}$. Como quer que seja, os exemplos demonstram a pesca como uma atividade intensamente exercida. Nos princípios do século XIX, Auguste de Saint-Hilaire percorrendo a região em análise descreve-a, verificando-se que os núcleos populacionais continuavam dedicados à atividade. Em Saquarema

${ }^{58}$ AHU, Conselho Ultramarino, Brasil, Rio de Janeiro, caixa 19, documento 2152, fls. 15v., 16. Estes homens provavelmente pescavam tanto na costa, quanto nas lagunas de Araruama ou Saquarema, por lhe serem próximas. 
refere que os habitantes das margens da laguna e especialmente os da restinga eram todos pescadores, contornando a laguna por Araruama descreve o arraial de Mataruna cujo ofício dos habitantes era maioritariamente a pesca, passa em São Pedro da Aldeia onde assevera ser a atividade uma das principais ocupações dos indígenas, os quais, embora na pesca marítima costeira utilizassem apetrechos e técnicas mais desenvolvidos e produtivos introduzidos após a colonização, como se verá, na pesca lagunar recorreriam a apetrechos mais rudimentares como redes construídas por si, linhas e anzois ${ }^{59}$. Em Cabo Frio Saint-Hilaire afirma que a população era constituída, em grande parte, por pescadores, os homens mais ricos da cidade, os quais possuíam embarcações próprias e eram coadjuvados nas pescarias por escravos ${ }^{60}$, o que indica o seu rendimento elevado. Além de pescado do mar capturavam-se também camarões na laguna utilizando "[...] longas redes com a forma de coador, que se prendem a duas grandes varas ligadas em suas extremidades." ${ }^{61}$. As praias do Pontal, Prainha, do Anjo, e Praia Grande estavam povoadas por pescadores sendo as espécies mais capturadas a enxova, cavala, framinguete ${ }^{62}$, grassuma ${ }^{63}$, sarda, e principalmente,

${ }^{59}$ Auguste de Saint-Hilaire, Viagem pelo Distrito dos Diamantes e Litoral do Brasil com um Resumo Histórico das Revoluções do Brasil, da Chegada de D. João VI à América à Abdicação de D. Pedro, Rio de Janeiro, Companhia Editora Nacional, 1941, p. 278, 288, 312 , respetivamente. Em meados do século XX, a pesca da tainha e camarão exercia-se com diversas armadilhas fixas como o gancho, a estacada e o trimbobó na canoa, cuja influência seria indígena: Lísia Maria Cavalcante Bernardes e Nilo Bernardes, A pesca no litoral do Rio de Janeiro..., cit., p. 18-19, 22.

${ }^{60}$ Auguste de Saint-Hilaire, Viagem pelo Distrito dos Diamantes..., cit., p. 330-331.

${ }^{61}$ Auguste de Saint-Hilaire, Viagem pelo Distrito dos Diamantes..., cit., p. 333. A captura desta espécie mantinha-se no século XX, sendo utilizada a tarrafa e a rede de dois calões ou de cauda, esta última no canal do Itajurú: Lísia Maria Cavalcante Bernardes, Nilo Bernardes, A pesca no litoral do Rio de Janeiro..., cit., p. 20-21. A primeira arte trata-se de uma rede de cerco, que em Portugal, se documenta desde 1434, tomando maiores dimensões a partir do século XVI. No caso da segunda, parece tratar-se da mesma arte chamada em Portugal de rede-pé ou varredoura, documentada desde o século XII, porquanto, em ambos os casos, se aplica manobrada por dois homens caminhando ao longo das margens ou da praia e aplicando-a contra a corrente: Fernando Gomes Pedrosa, "A Evolução das Artes de Pesca em Portugal", Anais do Clube Militar Naval, vol. CXV (1985), p. 294, 304.

${ }^{62}$ Trata-se do xerelete (Caranx crysos), sendo framinguete o nome vulgar: Haroldo Travassos e Hermínia de Holanda Lima, "Contribuição ao estudo dos Carangídeos do Brasil", Arq. Ciên. Mar., 15-1 (1975), (http://setores.ufc.br/labomar/wp-content/uploads/2017/01/acm-1975-15-1-04. pdf, consultado em: 02/04/2017), p. 38.

${ }^{63}$ Trata-se do nome vulgar aplicado ao chicharro (Punctatos): Haroldo Travassos, Hermínia de Holanda Lima, "Contribuição ao estudo dos Carangídeos do Brasil”..., cit., p. 38. 
a tainha ${ }^{64}$. Por aqui se depreende que as pescarias particulares, presentes nas praias no século XVIII, bem como as localidades fundadas no entorno lagunar, se tornaram em núcleos piscatórios, os quais, em meados do século $\mathrm{XX}$, ainda subsistiam enquanto localidades ligadas à pesca marítima e lagunar ${ }^{65}$.

\subsection{A influência portuguesa no desenvolvimento da pesca em Cabo Frio}

A documentação coeva fornece poucos dados no que diz respeito à atividade piscatória, embora expresse a estrita relação entre os habitantes da região e a laguna ou o mar ${ }^{66}$. Não obstante a aparente exiguidade documental, alguma informação demonstra o desenvolvimento da pesca na região de Cabo Frio após a colonização portuguesa, especialmente no que respeita à pesca costeira. A importância desta atividade na área em apreço evidencia-se, num primeiro momento, pela proliferação de pescarias ao longo do seu litoral e concomitante dedicação dos seus habitantes a essa atividade. Com efeito, segundo a documentação, "[...] os moradores de Cabo frio contrataõ e vivem de pescaria, e mais dependem do mar e da sua alagôa, que da terra." ${ }^{\prime 67}$. Essa dependência das pescarias e a entrega à labuta piscatória remontava aos "[...] moradores adventicios de Cabo Frio, ocupados sô nas suas pescarias[...]”68. Tal dedicação espoletou várias disputas pela posse de pescarias na Ponta de Búzios, motivo de desavenças num longo processo entre a Companhia de Jesus e a câmara de Cabo Frio ${ }^{69}$. Num primeiro momento, essa zona litorânea não despertou o interesse dos moradores de Cabo Frio por ser afastada da cidade ${ }^{70}$.

${ }^{64}$ Auguste de Saint-Hilaire, Viagem pelo Distrito dos Diamantes..., cit., p. 336, 338-339, 342.

${ }^{65}$ Cf. Lísia Maria Cavalcante Bernardes e Nilo Bernardes, A pesca no litoral do Rio de Janeiro ..., cit.

${ }^{66}$ Lísia Maria Cavalcante Bernardes e Nilo Bernardes, A pesca no litoral do Rio de Janeiro..., cit., p. 24.

${ }^{67}$ AHU, Conselho Ultramarino, Brasil, Rio de Janeiro, caixa 22, documento 2432, fl. 19. Lísia Maria Cavalcante Bernardes e Nilo Bernardes, A pesca no litoral do Rio de Janeiro..., cit., p. 24.

${ }^{68}$ AHU, Conselho Ultramarino, Brasil, Rio de Janeiro, caixa 22, documento 2432, fl. 16v.

${ }^{69}$ Os pleitos movidos pela câmara contra os jesuítas começaram antes de 1684 (AHU, Conselho Ultramarino, Brasil, Rio de Janeiro, caixa 5, documento 503), havendo várias queixas quanto a posse de terras pelos religiosos (AHU, Conselho Ultramarino, Brasil, Rio de Janeiro, caixa 8 , documento 1555. Ibidem, caixa 10, documento 1046, fl. 1v.). A disputa sobre a Ponta de Búzios surge pelo menos desde 1717 (AHU, Conselho Ultramarino, Brasil, Rio de Janeiro, caixa 13, documento 1407, fl. 9v.) e perdura até 1756 (AHU, Conselho Ultramarino, Brasil, Rio de Janeiro, caixa 50, documento 2956).

${ }^{70}$ AHU, Conselho Ultramarino, Brasil, Rio de Janeiro, caixa 18, documento 2038, fls. 1, 12. 
Contudo, se tivermos em consideração a referida proliferação das pescarias, ocupando o litoral entre a cidade de Cabo Frio e a Ponta de Búzios, entendemos o ensejo da câmara em tomar as pescarias jesuítas, pois as restantes do litoral eram privadas e o povo não usufruía delas ${ }^{71}$. Além disso, em 1729 instalou-se uma armação para captura de baleias, tendo a câmara arrendado os terrenos para sua implantação ${ }^{72}$, nesse sentido, interessava comprovar que os mesmos lhe pertenciam.

Os processos relativos à questão da Ponta de Búzios facultam várias informações quanto à atividade da pesca na região. É comum afirmar-se que os portugueses pouca ou nenhuma influência tiveram na forma como se exerce a atividade piscatória no Brasil. Os apetrechos utilizados e as respetivas técnicas aplicadas na captura do pescado são apontadas como resultado do conhecimento das populações indígenas ${ }^{73}$. Como se viu os principais métodos e apetrechos piscatórios utilizados pelos indígenas que habitavam a região em apreço eram rudimentares. A documentação referente a esta contenda demonstra a influência que os portugueses tiveram no desenvolvimento da pesca costeira, especialmente através da introdução de técnicas piscatórias mais produtivas. Em 1722, as redes de arrasto já haviam sido introduzidas e eram utilizadas na Ponta de Búzios, onde o sargento-mor Tomás da Costa era detentor de " [...] huma rede grande de pescar, e alguns escrauos, tinha, e ainda tera lá junto á praya huma casinha cuberta de palha, para a fabrica desta rede em certos meses do anno. E rara vez sucçede ir algum dos mays pescar aquela parage, por lhe ficar longe, e porque he raro o que tem posses para conseruar rede de arrasto." ${ }^{\prime 74}$. Por aqui se denota que o empreendimento, apesar de sazonal, seria vultuoso, uma vez que envolvia mão-de-obra e redes de arrasto cuja posse e manutenção eram dispendiosas. Os indígenas, por seu turno, já recorreriam a técnicas mais desenvolvidas, contrariamente àquelas tradicionalmente utilizadas antes da

\footnotetext{
${ }^{71}$ Ibidem, fl. $22 \mathrm{v}$.

${ }^{72}$ AHU, Conselho Ultramarino, Brasil, Rio de Janeiro, caixa 20, documento 2202. AHU, Conselho Ultramarino, Brasil, Rio de Janeiro, caixa 22, documento 2432, fl. 10v.

${ }^{73}$ E.g. Alberto Ribeiro Lamego, O Homem e a Restinga..., cit., p. 157-158. Lísia Maria Cavalcante Bernardes e Nilo Bernardes, A pesca no litoral do Rio de Janeiro..., cit., p. 18. Lísia Maria Cavalcante Bernardes, "Pescadores da ponta do Caju-Aspectos da contribuição de Portuguêses e Espanhóis para o desenvolvimento da pesca na Guanabara", Revista Brasileira de Geografia, vol. 20, n. ${ }^{\circ} 2$ (1958), p. 181.

${ }^{74}$ AHU, Conselho Ultramarino, Brasil, Rio de Janeiro, caixa 13, documento 1407, fl. 9v. Lísia Maria Cavalcante Bernardes, Nilo Bernardes, A pesca no litoral do Rio de Janeiro..., cit., p. 24 .
} 
chegada dos colonos ${ }^{75}$. Segundo a câmara de Cabo Frio, as pescarias não eram para usufruto dos índios, mas antes para comércio do pescado capturado em benefício dos jesuítas, o qual era expedido em embarcações ${ }^{76}$. Por outro lado, quando se efetuava a repartição do sal das salinas existentes na laguna de Araruama os índios apropriavam-se do mineral ${ }^{77}$. Tais descrições demonstram a elevada produção piscatória pela sua necessidade para conservação do peixe e posterior comércio, subentendendo-se a utilização de utensílios piscatórios de grande envergadura, como as redes de arrasto, por forma a proceder a uma captura elevada. Com efeito, nas suas pescarias os índios possuíam uma “[...]

${ }^{75}$ O padre Simão de Vasconcelos refere em 1663 que acrescendo ao uso de flechas e envenenamento dos peixes, os indígenas adotaram dos portugueses os anzois e os covos, sendo que no mar pescavam ligando linhas e anzois entre três ou quatro canoas: Padre Simão de Vasconcellos, Chronica da Companhia de Jesu do Estado do Brasil..., cit., p. LXXVIII. Como vimos, apesar de terem redes de dimensão pequena, os indígenas, neste litoral, adotaram redes maiores introduzidas pelos europeus: Jean de Léry, Viagem à terra do Brasil, São Paulo, Livraria Martins Editora, 1941, p. 148-150.

${ }^{76}$ Referem os oficiais da câmara que na Ponta de Búzios era "[...] donde costumam pescar os Indios, ou para milhor dizer os dittos Relligiozos Padres tinhaõ Pescarias, naõ para os Indios senaõ para fazerem negocio, como actualmente o estaõ vendendo a embarcacoẽns, que vem a este porto fazerem negocio, e ainda aos proprios Indios." AHU, Conselho Ultramarino, Brasil, Rio de Janeiro, caixa 18, documento 2038, fl.23. Em Portugal, desde tempos medievos, o clero controlava pescarias e o peixe assumia uma importância acrescida na dieta alimentar devido à regulamentação canónica: António Henrique de Oliveira Marques, Portugal na Crise dos Séculos XIV e XV, vol. IV, Lisboa, Editorial Presença, 1987, p. 111, 464-465.

${ }^{77}$ AHU, Conselho Ultramarino, Brasil, Rio de Janeiro, caixa 18, documento 2038, fl. 23. O sal era importante para a conservação do pescado através da salga, prática utilizada em Portugal (e.g. Rosalina B. da Silva Cunha, Subsídios para a conservação do peixe em Portugal do século XII ao XVI, Separata do Boletim da Biblioteca da Universidade de Coimbra. Vol. XXIX, Coimbra, Universidade de Coimbra, 1972, p. 5-72). A existência de salinas naturais e a posterior introdução de salinas artificiais em Cabo Frio (vd. Alberto Ribeiro Lamego, O Homem e a Restinga..., cit., p. 164-184. Werther Holzer, "O Sabor do Sal: Paisagens Vernaculares da Araruama", Geograficidade, v. 4 (2014), (http://www.uff.br/posarq/geograficidade/revista/index.php/ geograficidade/issue/archive, consultado em 25.09.2016), Olegário Nelson Azevedo Pereira, Elza Maria Neffa Vieira de Castro, Maria Rosário Bastos, João Alveirinho Dias e Maria Antonieta da Conceição Rodrigues, "De Aveiro e Figueira da Foz (PT) para Arraial do Cabo (BR): influência de técnicas portuguesas na salicultura da laguna de Araruama, Rio de Janeiro, Brasil" in Sílvia Dias Pereira, Maria Antonieta da Conceição Rodrigues, Ana Catarina Garcia e Luís Cancela da Fonseca (ed.), Entre Rios e Mares: um Património de Ambientes, História e Saberes/Tomo V da Rede BrasPor, Rio de Janeiro, FAPERJ, 2016, p. 47-61) supriam a necessidade do mineral para salga do pescado provindo da atividade piscatória efetuada na região. 
caza para seu recolhimento nas ocazioens da pesca, e para recolherem as redes, e mais fabrica della." ${ }^{78}$.

A indicação da tipologia de utensilagem piscatória utilizada não permite descortinar se as redes utilizadas nas pescarias ao longo do litoral em análise eram de arrasto. Contudo, alguns elementos levam a conjeturar tal situação. Nas pescarias descritas em 1731, entre os proprietários encontra-se Tomás da Costa, o mesmo que aplicava redes de arrasto na Ponta de Búzios ${ }^{79}$, o que leva a crer o emprego da mesma técnica e apetrecho. Embora não se indique a tipologia de redes utilizadas nessas pescarias, quase todas tinham instalações para sua produção e manutenção, tal como na Ponta de Búzios, subentendendo-se tratar-se de apetrechos com envergadura elevada. Além disso, os seus proprietários eram indivíduos com cargos militares ou de liderança e ordens religiosas, portanto com posses económicas para tais empreendimentos ${ }^{80}$. Talvez por isso em 1731 os pescadores menos abastados se queixassem dos grandes proprietários, os quais, estabeleciam "caza de redes e toda a fabrica de pescarya", lançando suas "redes para pescar", fazendo "cercos ao peixe", não permitindo que outros utilizassem os terrenos confinantes com o mar para exercerem a atividade, o que na prática era ilegal $^{81}$. Tudo isto leva a crer que as técnicas de cerco envolvente, vulgarmente chamadas de arrasto para terra ${ }^{82}$, eram as aplicadas neste litoral para a pesca marítima costeira. Mais ainda, se considerarmos as condições oferecidas pelo meio, com praias extensas e leito marinho arenoso, permitindo as manobras das redes e das embarcações, acrescendo o fenómeno da ressurgência, o qual, como se viu, proporciona especialmente espécies de pelágicos como a sardinha. Mormente com tais condições naturais, este pescado é capturado recorrendo a essa técnica, aplicando-se consequentemente artes envolventes de arrasto pelo fundo, cuja rede é recolhida a partir da praia ${ }^{83}$.

${ }^{78}$ AHU (Lisboa), Conselho Ultramarino, Brasil, Rio de Janeiro, caixa 18, documento 2038, fl. $27 \mathrm{v}$.

${ }^{79}$ Além da pescaria na Ponta de Búzios, localizada na praia da Ferradura Grande, também detinha uma na praia dos Anjos (AHU, Conselho Ultramarino, Brasil, Rio de Janeiro, caixa 22, documento 2432, fls. 13-13v.).

${ }^{80}$ Cf. AHU, Conselho Ultramarino, Brasil, Rio de Janeiro, caixa 22, documento 2432, fls. 12-14.

${ }^{81}$ AHU, Conselho Ultramarino, Brasil, Rio de Janeiro, caixa 23, documento 2509.

${ }^{82}$ Inês Amorim, "Recursos marítimos e tecnologia no séc. XVIII - pesca, sal e moliço no litoral e ria de Aveiro", O litoral em perspectiva histórica (séc. XVI a XVIII), Porto, Instituto de História Moderna, 2002, p. 192.

${ }^{83}$ Henrique Souto, Comunidades de pesca artesanal em Portugal, Lisboa, Academia de Marinha (http://www.henrique-souto.net/resources/Comunidades\%20de $\% 20 \mathrm{Pesca} \% 20$ Artesanal\%20em\%20Portugal.pdf, consultado em 07.04.2017), p. 14-16. 
As redes de arrasto eram bastante utilizadas em Portugal, especialmente em litorais com tais condições naturais ${ }^{84}$, técnica aparentemente reproduzida em Cabo Frio após a sua colonização. No século XIX, Saint-Hilaire ao visitar a praia do Anjo assegurava ser totalmente habitada por brancos (subentendendo-se descendência europeia, logo, portuguesa), os quais exerciam a pesca com redes, embora não se indique a sua tipologia ${ }^{85}$. Como quer que seja, já em meados do século XX, as redes de arrasto eram o apetrecho mais utilizado no litoral em análise ${ }^{86}$.

\section{Conclusão}

As condições naturais na região de Cabo Frio, nomeadamente a existência do fenómeno de ressurgência costeira ou afloramento costeiro (coastal upwelling) no seu litoral e a formação do sistema lagunar de Araruama, providenciaram variados recursos piscícolas potenciando a atividade piscatória. Antes da colonização portuguesa, os indígenas que habitavam aquele litoral tinham a pesca como atividade de subsistência aplicando técnicas e apetrechos rudimentares. A colonização portuguesa do território ocorreu especialmente no século XVII, num esforço de ocupação territorial através da fundação de núcleos de povoamento constituídos por colonos e indígenas. Com um modus vivendi dedicado predominantemente à pesca, surgiram povoações dedicadas à atividade. As pescarias estabelecidas ao longo deste litoral, onde ocorrem especialmente espécies de pelágicos, eram controladas por indivíduos e instituições religiosas, cuja condição económica permitiu a aplicação de apetrechos mais desenvolvidos e consequentemente mais dispendiosos. Tudo indica, por isso, que a técnica de cerco envolvente era aquela aplicada na pesca marítima costeira. A sua introdução terá surgido após a colonização e subsistido até ao século XX. Na laguna de Araruama, a pesca era exercida com utensílios como as redes e anzois, aplicados no século XIX pelos índios moradores de São Pedro da Aldeia, e armadilhas fixas de redes, colocadas pelos moradores de Cabo Frio no canal do Itajurú para captura de camarão. No século XX, as artes piscatórias mais utilizadas eram as armadilhas fixas como o gancho,

${ }^{84}$ Para os diversos apetrechos aplicados nas técnicas de cerco envolvente, entre outros, cf. Fernando Gomes Pedrosa, A Evolução das Artes de Pesca em Portugal..., cit., p. 294-299. Nuno Luís Madureira e Inês Amorim, História do Trabalho e das Ocupações, vol. II, Oeiras, Celta Editora, 2001, passim.

${ }^{85}$ Auguste de Saint-Hilaire, Viagem pelo Distrito dos Diamantes..., cit., p. 339.

${ }^{86}$ Lísia Maria Cavalcante Bernardes, Nilo Bernardes, A pesca no litoral do Rio de Janeiro..., cit., p. 24-25. 
estacada ou trimbobó na canoa, e as redes de cerco, como a rede de dois calões ou de cauda e a tarrafa, com as quais se capturavam especialmente as tainhas e o camarão. Conclui-se, portanto, que na pesca costeira, os portugueses introduziram técnicas mais produtivas, enquanto na pesca lagunar parece ter subsistido o emprego de técnicas com influência indígena. Não obstante, torna-se necessário um aprofundamento no estudo destas questões, recorrendo-se a outras tipologias documentais por forma a colmatar a falta de elementos que melhor sustentem esta hipótese. 